\title{
Intermediate-Temperature Operation of Sodium Secondary Batteries with High Rate Capability and Cyclability Using Ionic Liquid Electrolyte
}

\section{$\operatorname{AUTHOR}(\mathrm{S})$ :}

Matsumoto, Kazuhiko; Chen, Chih-Yao; Kiko, Tomohiro; Hwang, Jinkwang; Hosokawa, Takafumi; Nohira, Toshiyuki; Hagiwara, Rika

\section{CITATION:}

Matsumoto, Kazuhiko ...[et al]. Intermediate-Temperature Operation of Sodium Secondary Batteries with High Rate Capability and Cyclability Using Ionic Liquid Electrolyte. ECS Transactions 2016, 75(15): 139-145

\section{ISSUE DATE:}

2016

URL:

http://hdl.handle.net/2433/230505

\section{RIGHT:}

This is the accepted version of the article, which has been published in final form at https://doi.org/10.1149/07515.0139ecst.; この論文は出版社版でありません。引用の際に は出版社版をご確認ご利用ください。; This is not the published version. Please cite only the published version. 


\title{
Intermediate-Temperature Operation of Sodium Secondary Batteries with High Rate Capability and Cyclability Using Ionic Liquid Electrolyte
}

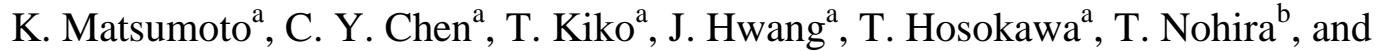 \\ R. Hagiwara ${ }^{a}$ \\ ${ }^{a}$ Graduate School of Energy Science, Kyoto University, Yoshida, Kyoto 606-8501, \\ JAPAN \\ ${ }^{\mathrm{b}}$ Institute of Advanced Energy, Kyoto University, Gokasho, Uji 611-0011, JAPAN
}

Electrochemical behavior of $\mathrm{Na}$ metal is one of the key factors to construct high performance $\mathrm{Na}$ secondary batteries. The present study reports temperature dependence of $\mathrm{Na}$ metal deposition/dissolution efficiency and morphology of the deposited $\mathrm{Na}$ metal in the $\mathrm{Na}[\mathrm{FSA}]-\left[\mathrm{C}_{2} \mathrm{C}_{1} \mathrm{im}\right][\mathrm{FSA}]$ ionic liquids $\left(\mathrm{C}_{2} \mathrm{C}_{1} \mathrm{im}^{+}=\right.$ 1-ethyl-3-methylimidazolium and $\mathrm{FSA}^{-}=$ bis(fluorosulfonyl)amide). The deposition/dissolution efficiency shows the minimum at $298 \mathrm{~K}$ and increases by both increasing and decreasing temperature. Optical microscopic analysis reveals that $\mathrm{Na}$ metal is grown in a whisker-like form during cathodic polarization at $298 \mathrm{~K}$, whereas smooth deposits are observed at $363 \mathrm{~K}$. Although the deposition form at $273 \mathrm{~K}$ is also whisker-like, the thickness and length of each whisker is smaller and shorter, respectively, than those at $298 \mathrm{~K}$. Such differences in morphology affect the Na metal deposition/dissolution efficiencies.

\section{Introduction}

Ionic liquid electrolytes are widely studied to construct safe electrochemical devices owing to their unique properties such as low volatility, low flammability, and wide liquid-phase temperature range (1), which includes the case of $\mathrm{Na}$ secondary batteries which are expected as an alternative energy storage device near future (2-5). Ionic liquids based on sulfonylamide anions (bis(fluorosulfonyl)amide anion ( $\left.\mathrm{FSA}^{-}\right)$) are attractive as electrolytes owing to their low melting point, low viscosity, and high ionic conductivity as well as high stability against cathodic reactions (6-8). Our previous works revealed that FSA-based ionic liquid electrolytes show appealing properties for $\mathrm{Na}$ secondary batteries from room temperature to intermediate temperature $(4,5)$. In particular, intermediate-temperature operation of $\mathrm{Na}$ secondary batteries is quite attractive to enhance their performance using waste heat or self-heating of the batteries, and a variety of positive and negative electrodes show good performance in this system (9-12).

Steady utilization of a $\mathrm{Na}$ metal negative electrode is one of the key technologies to realize a high-rate and long-life $\mathrm{Na}$ secondary batteries. It was reported that $\mathrm{Na}$ metal can be reversibly deposited and dissolved in the $\mathrm{Na}$ [FSA]-[C $\left.\mathrm{C}_{2} \mathrm{C}_{1} \mathrm{im}\right][\mathrm{FSA}]\left(\mathrm{C}_{2} \mathrm{C}_{1} \mathrm{im}^{+}=1\right.$ ethyl-3-methylimidazolium and $\mathrm{FSA}^{-}=$bis(fluorosulfonyl)amide) ionic liquid electrolyte (4). This is based on the formation of stable surface film on the Na metal according to the recent works $(13,14)$. The present study reports temperature dependence of 
deposition/dissolution efficiency and morphology of $\mathrm{Na}$ metal in the $\mathrm{Na}[\mathrm{FSA}]-$ $\left[\mathrm{C}_{2} \mathrm{C}_{1} \mathrm{im}\right][\mathrm{FSA}]$ ionic liquid system.

\section{Experimental}

\section{$\underline{\text { Materials }}$}

Air sensitive materials were handled in a glovebox under a dried and deoxygenated argon atmosphere. Volatiles were handled in a vacuum line made of stainless steel. The $\mathrm{Na}$ [FSA]-[ $\left.\mathrm{C}_{2} \mathrm{C}_{1} \mathrm{im}\right][\mathrm{FSA}]$ (30:70 in molar ratio) ionic liquid was prepared by mixing dry $\mathrm{Na}[\mathrm{FSA}]$ and $\left[\mathrm{C}_{2} \mathrm{C}_{1} \mathrm{im}\right][\mathrm{FSA}]$.

\section{$\underline{\text { Analysis }}$}

Electrochemical measurements were performed with a Hokuto Denko chargedischarge system (HJ1001SD8). The Na deposition/dissolution test was performed in a two-electrode cell at a current density of $1.0 \mathrm{~mA} \mathrm{~cm}{ }^{-2}$ using a Hokuto HJ1001SD8 system. Sodium metal of $0.8 \mathrm{C} \mathrm{cm}^{-2}$ was first deposited on a $\mathrm{Cu}$ substrate and $\mathrm{Na}$ deposition and dissolution of $0.2 \mathrm{C} \mathrm{cm}^{-2}$ were repeated until the electrode potential reached $0.5 \mathrm{~V}$ vs. $\mathrm{Na}^{+} / \mathrm{Na}$ during the dissolution. The average cycle efficiency of $\mathrm{Na}$ deposition/dissolution $\left(\varepsilon_{\text {cycle }}\right)$ is obtained according to the following equation (Equation 1 ) $(4,15)$ :

$$
\varepsilon_{\text {cycle }}=N_{\text {eff }} \cdot Q_{\text {cycle }} /\left(Q_{\text {ex }}+N_{\text {eff }} \cdot Q_{\text {cycle }}\right)
$$

where $N_{\text {eff }}$ is cycle number until the electrode potential reached $1.0 \mathrm{~V}$ vs. $\mathrm{Na} / \mathrm{Na}^{+}, Q_{\text {cycle }}$ is the electric charge for $\mathrm{Na}$ deposition/dissolution for one cycle $\left(0.02 \mathrm{C} \mathrm{cm}^{-2}\right)$, and $Q_{\mathrm{ex}}$ is the extra amount of electricity deposited prior to the cycling $\left(0.08 \mathrm{C} \mathrm{cm}^{-2}\right)$. A sodium metal counter electrode was used for this test.

Morphology of $\mathrm{Na}$ metal electrodes was visually confirmed by using a twoelectrode beaker cell. In each cycle, deposition and dissolution of $\mathrm{Na}$ metal was performed at a current density of $0.2 \mathrm{~mA} \mathrm{~cm}^{-2}$ for $1000 \mathrm{~s}$. This cycle was continued 50 times. Deposited Na metal was observed by optical microscopy. Alternatively, an in situ optical microscopy was used to evaluate the morphology at the initial state. Deposition of $\mathrm{Na}$ metal was performed $5 \mathrm{~mA} \mathrm{~cm}^{-2}$ for $200 \mathrm{~s}$

\section{Results and discussion}

Temperature dependence of cycle efficiency for Na metal deposition/dissolution

Table I summarizes cycle efficiency $\left(\eta_{\text {eff }}\right)$ for $\mathrm{Na}$ metal deposition/dissolution in $\mathrm{Na}[\mathrm{FSA}]-\left[\mathrm{C}_{2} \mathrm{C}_{1} \mathrm{im}\right][\mathrm{FSA}]$ (30:70 in molar ratio) at different temperatures. Figure 1 shows the result of deposition/dissolution test at $298 \mathrm{~K}$. The $\eta_{\text {eff }}$ value at $298 \mathrm{~K}$ is $64 \%$ as the potential reaches $1.0 \mathrm{~V}$ vs. $\mathrm{Na}^{+} / \mathrm{Na}$ at the 7 th cycle. At $363 \mathrm{~K}, \eta_{\text {eff }}$ is highly improved to $97 \%$ reaching 152 cycles. This behavior agrees with a previous work (4) and suggests that $\eta_{\text {eff }}$ is not reduced by the reaction of $\mathrm{Na}$ metal with the ionic liquid because such a reaction is usually accelerated by the elevation of temperatures. 
It is should be noted that $\eta_{\text {eff }}$ is also improved by decreasing temperature ( $82 \%$ after 18 cycles), which suggests that there could be more than two factors affecting the $\eta_{\text {eff }}$ values.

TABLE I. Summary of Na metal deposition/dissolution cycle tests in Na[FSA]-[C2C1im][FSA] (30:70)

\begin{tabular}{ccc}
\hline Temperature $/ \mathbf{K}$ & Cycle number & Cycle efficiency $\left(\boldsymbol{\eta}_{\text {eff }}\right) / \boldsymbol{\%}$ \\
\hline 273 & 18 & 82 \\
283 & 1 & 73 \\
298 & 7 & 64 \\
323 & 16 & 80 \\
343 & 49 & 92 \\
353 & 55 & 93 \\
363 & 152 & 97 \\
\hline
\end{tabular}

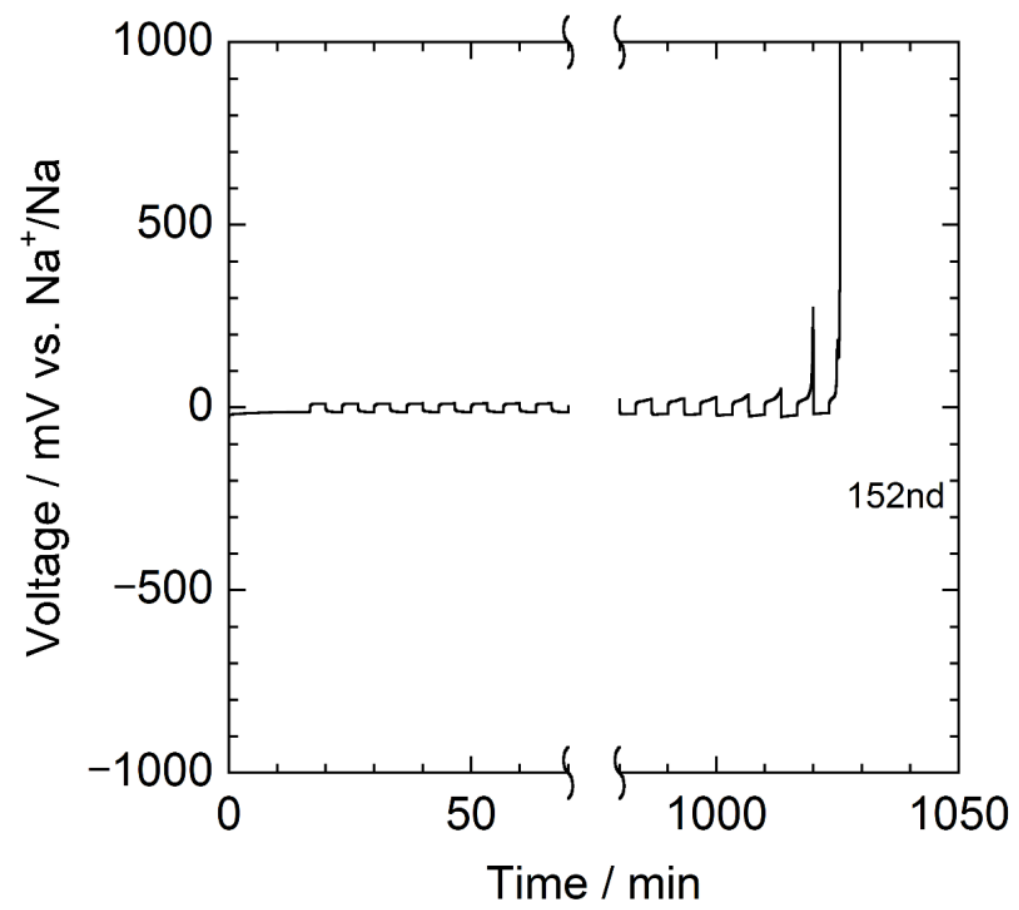

Figure 1. Voltage profiles during the $\mathrm{Na}$ deposition/dissolution tests on a $\mathrm{Cu}$ plate electrode in $\mathrm{Na}[\mathrm{FSA}]-\left[\mathrm{C}_{2} \mathrm{C}_{1}\right.$ im] [FSA] (30:70) at $363 \mathrm{~K}$. Current density: $1.0 \mathrm{~mA} \mathrm{~cm}$.

Temperature dependence of morphology of the deposited Na metal

Figure 2 shows the appearance of $\mathrm{Na}$ electrodes after alternate $\mathrm{Na}$ metal deposition/dissolution for 50 cycles. These electrochemical tests were performed in a two-electrode beaker cell at 273, 298, and $363 \mathrm{~K}$. The appearance of the electrodes apparently changes after 50 cycles. The surface of the Na electrodes is covered with voluminous but sparsely deposited $\mathrm{Na}$ metal at $298 \mathrm{~K}$. Although the deposited Na metal at $273 \mathrm{~K}$ is slightly denser than that at $298 \mathrm{~K}$, it is still quite fluffy. In the case of the electrode at $363 \mathrm{~K}$, no change is observed and metallic luster is preserved even after 50 cycles. 

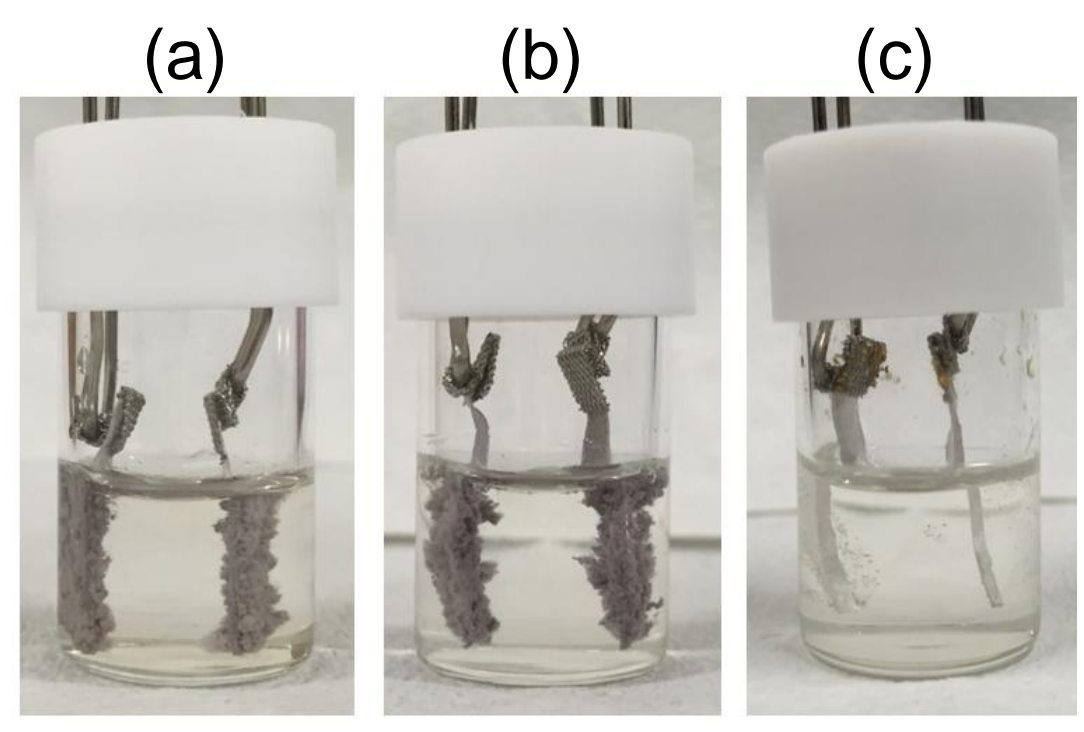

Figure 2. Appearance of the deposited $\mathrm{Na}$ metal in $\mathrm{Na}[\mathrm{FSA}]-\left[\mathrm{C}_{2} \mathrm{C}_{1} \mathrm{im}\right][\mathrm{FSA}](30: 70)$ at (a) $273 \mathrm{~K}$, (b) $298 \mathrm{~K}$, and (c) $363 \mathrm{~K}$. Current density: $0.2 \mathrm{~mA} \mathrm{~cm}{ }^{-2}$.

The deposits at 273 and $298 \mathrm{~K}$ were further examined by optical microscopic analysis as shown in Figure 3. In both the cases, whisker-like deposits with a diameter of a few $\mu \mathrm{m}$ are complicatedly tangled each other. Although some of them have a dendritic form, they are one-dimensionally grown with some bending points in most cases. By carefully looking at the images, one can notice that the deposits at $298 \mathrm{~K}$ are thicker in diameter than the one at $273 \mathrm{~K}$. These observations suggest that the morphology of the deposits is highly dependent on the temperature and formation of whisker-like Na metal increases the amount of dead sodium during deposition, leading to the low $\eta_{\text {eff }}$ value.

Morphology during the initial deposition of $\mathrm{Na}$ metal on a $\mathrm{Cu}$ plate was observed using an in situ optical microscopic system. This system is close to the two-electrode coin cell used to estimate $\eta_{\text {eff. }}$ Figure 4 shows optical images of the Na metal deposits at 273, 298 , and $363 \mathrm{~K}$. These deposits were obtained by cathodic polarization at a constant current density of $5 \mathrm{~mA} \mathrm{~cm}{ }^{-2}$ for $200 \mathrm{~s}$. For the cathodic polarization at $298 \mathrm{~K}$, nucleation points were relatively sparse at the beginning, and whisker-like $\mathrm{Na}$ metal was grown perpendicular to the substrate. After the polarization (Figure 4 (a)), the surface of the substrate is covered with the deposits but the surface of the $\mathrm{Cu}$ substrate is still observable. Two-dimensional depth profile analysis revealed that the surface of the deposits is significantly rough and the highest whisker is grown up to $77 \mu \mathrm{m}$ from the surface of the $\mathrm{Cu}$ substrate. At $273 \mathrm{~K}$, nucleation occurs more densely than that at $298 \mathrm{~K}$ at the initial stage of cathodic polarization. Although the growth of the deposits obtained after polarization at $273 \mathrm{~K}$ is also uneven (Figure (b)), long whisker is not observed and the difference in height is not greater than $8 \mu \mathrm{m}$. These results indicate that nucleation is more predominant than nuclear growth at $273 \mathrm{~K}$, which causes the difference in the $\eta_{\text {eff }}$ values at 273 and $298 \mathrm{~K}$. Nucleation at $363 \mathrm{~K}$ was not very dense and the deposits were grown in a hemispherical shape with the height of a few $\mu \mathrm{m}$ (Figure 4 (c)). Formation of such dense and smooth deposits leads to the high $\eta_{\text {eff }}$ value at $363 \mathrm{~K}$. 

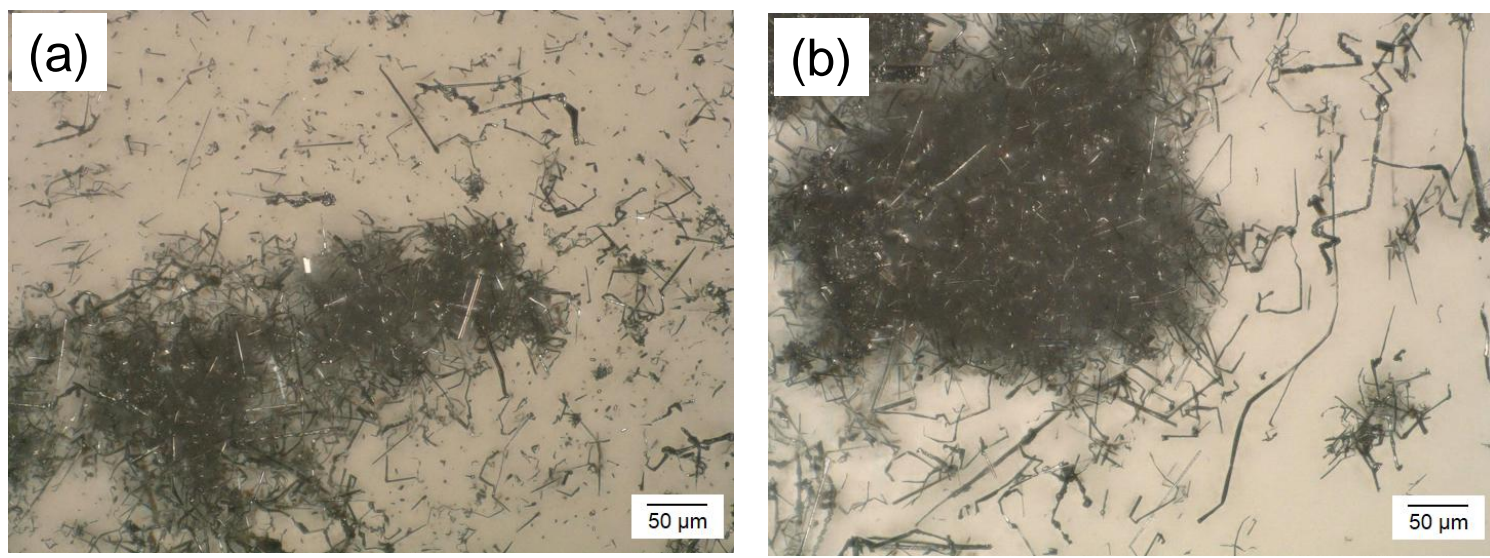

Figure 3. Optical microscopic images of $\mathrm{Na}$ metal deposited on $\mathrm{Na}$ metal electrodes in $\mathrm{Na}[\mathrm{FSA}]-\left[\mathrm{C}_{2} \mathrm{C}_{1} \mathrm{im}\right][\mathrm{FSA}](30: 70)$ at (a) $273 \mathrm{~K}$ and (b) $298 \mathrm{~K}$.
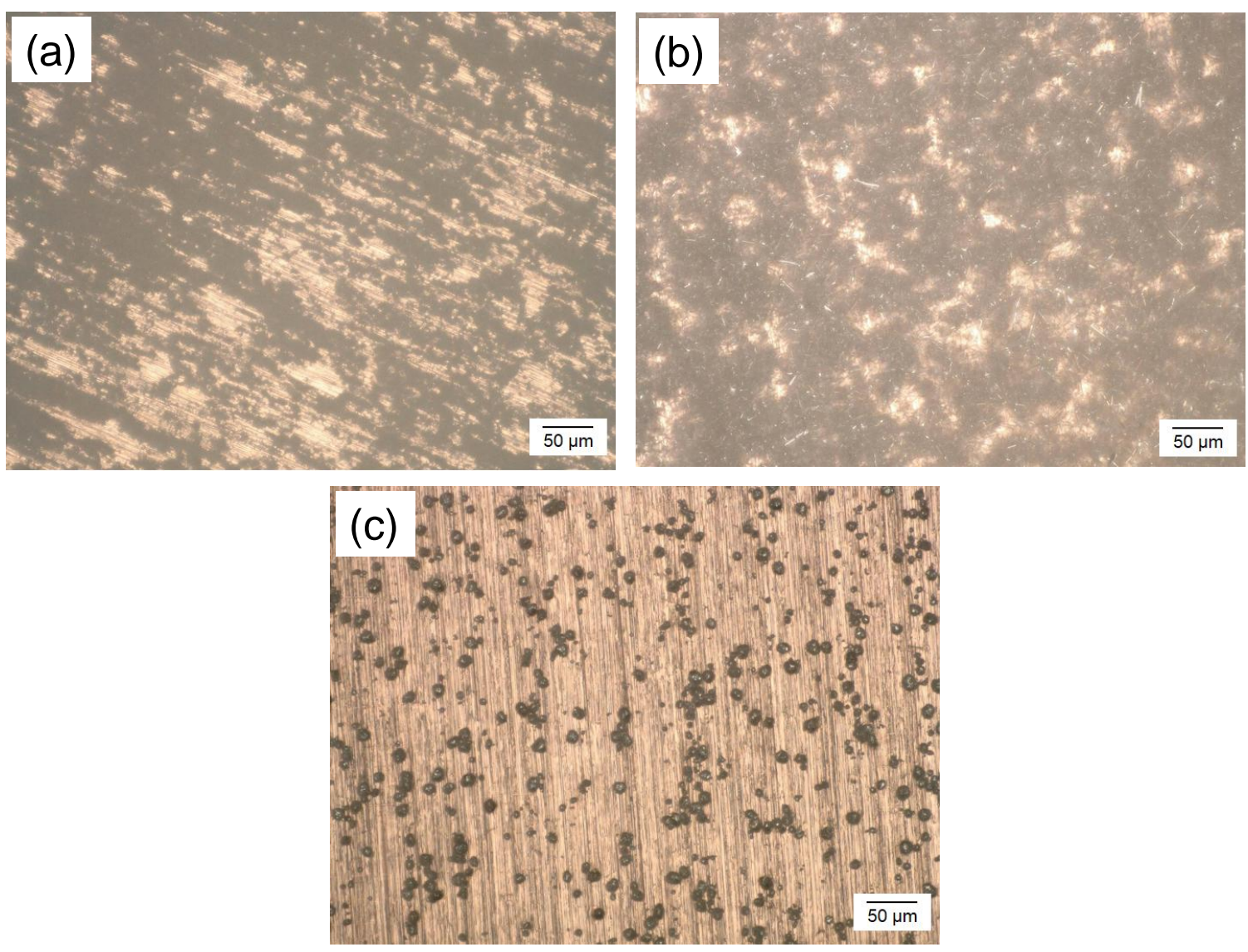

Figure 4 Optical images of deposited $\mathrm{Na}$ metal on a $\mathrm{Cu}$ plate electrode in $\mathrm{Na}[\mathrm{FSA}]-$ [C $\left.\mathrm{C}_{2} \mathrm{C}_{1} \mathrm{im}\right][\mathrm{FSA}]$ (30:70) at (a) 273, (b) 298, and (c) $363 \mathrm{~K}$. Current density: at $5 \mathrm{~mA} \mathrm{~cm}$. Quantity of electricity: $1.0 \mathrm{C} \mathrm{cm}^{-2}$. 


\section{Conclusions}

In this study, temperature dependence of $\mathrm{Na}$ metal deposition/dissolution efficiency and morphology of the deposited $\mathrm{Na}$ metal was investigated in the $\mathrm{Na}[\mathrm{FSA}]-$ $\left[\mathrm{C}_{2} \mathrm{C}_{1} \mathrm{im}\right][\mathrm{FSA}]$ ionic liquids. The deposition/dissolution efficiency had the minimum at $298 \mathrm{~K}$ and increased at both lower and higher temperatures. The shape of the deposited $\mathrm{Na}$ metal was whisker-like at $298 \mathrm{~K}$ and spherical at $363 \mathrm{~K}$. The deposition form at $273 \mathrm{~K}$ was also whisker-like, each whisker having smaller thickness and shorter length than those at $298 \mathrm{~K}$. Such differences in morphology is considered to affect the Na metal deposition/dissolution efficiencies.

\section{Acknowledgments}

This study was partly supported by Advanced Low Carbon Technology Research and Development Program (ALCA) of Japan Science and Technology Agency (JST) and Japanese Ministry of Education, Culture, Sports, Science and Technology (MEXT) program "Elements Strategy Initiative to Form Core Research Center".

\section{References}

1. H. Ohno, Electrochemical Aspects of Ionic Liquids, John Wiley \& Sons Inc., Hoboken, New Jersey, 2011.

2. S. A. M. Noor, P. C. Howlett, D. R. MacFarlane, and M. Forsyth, Electrochim. Acta, 114, 766 (2013).

3. D. Monti, E. Jonsson, M. R. Palacin, and P. Johansson, J. Power Sources, 245, 630 (2014).

4. K. Matsumoto, T. Hosokawa, T. Nohira, R. Hagiwara, A. Fukunaga, K. Numata, E. Itani, S. Sakai, K. Nitta, and S. Inazawa, J. Power Sources, 265, 36 (2014).

5. K. Matsumoto, Y. Okamoto, T. Nohira, and R. Hagiwara, J. Phys. Chem. C, 119, 7648 (2015).

6. M. Ishikawa, T. Sugimoto, M. Kikuta, E. Ishiko, and M. Kono, J. Power Sources, 162, 658 (2006).

7. H. Matsumoto, H. Sakaebe, K. Tatsumi, M. Kikuta, E. Ishiko, and M. Kono, J. Power Sources, 160, 1308 (2006).

8. H. Zhang, W. F. Feng, J. Nie, and Z. B. Zhou, J. Fluorine Chem., 174, 49 (2015).

9. T. Yamamoto, T. Nohira, R. Hagiwara, A. Fukunaga, S. Sakai, K. Nitta, and S. Inazawa, J. Power Sources, 217, 479 (2012).

10. C. S. Ding, T. Nohira, R. Hagiwara, K. Matsumoto, Y. Okamoto, A. Fukunaga, S. Sakai, K. Nitta, and S. Inazawa, J. Power Sources, 269, 124 (2014).

11. A. Fukunaga, T. Nohira, R. Hagiwara, K. Numata, E. Itani, S. Sakai, K. Nitta, and S. Inazawa, J. Power Sources, 246, 387 (2014).

12. C. Y. Chen, K. Matsumoto, T. Nohira, C. S. Ding, T. Yamamoto, and R. Hagiwara, Electrochim. Acta, 133, 583 (2014).

13. T. Hosokawa, K. Matsumoto, T. Nohira, R. Hagiwara, A. Fukunaga, S. Sakai, and K. Nitta, J. Phys. Chem. C, 120, 9628 (2016).

14. I. A. Shkrob, T. W. Marin, Y. Zhu, and D. P. Abraham, J. Phys. Chem. C, 118, 19661 (2014). 
15. K. Matsumoto, R. Taniki, T. Nohira, and R. Hagiwara, J. Electrochem. Soc., 162, A1409 (2015). 